Eur. J. Clin. Chem. Clin. Biochem.

Vol. 29, 1991, pp. 189-192

(C) 1991 Walter de Gruyter \& Co. Berlin · New York

\title{
Development of a Luminescence Immunoassay for Follitropin Suitable for Clinical Routine ${ }^{1}$ )
}

\author{
By G. Biro, Asfoura Samira, H. Butz, E. Leicht and K. F. Weinges \\ Medizinische Klinik und Poliklinik - Innere Medizin II - der Universität des Saarlandes, Homburg/Saar, \\ Germany
}

(Received July 25/November 7, 1990)

Summary: We developed a luminescence immunoassay (LIA) for follitropin, based on the synthesis of a follitropin-N-(4-aminobutyl)-N-ethylisoluminol conjugate. The luminescence tracer was purified by gel chromatography. Antibody-bound and non-bound tracer fractions were separated by using a second antibody reagent bound to magnetic particles. The assay can be performed within 24 hours and is sufficiently sensitive for the measurement of all clinically relevant follitropin concentrations including the subnormal range.

\section{Introduction}

In view of the well-known disadvantages of radioactive labels, non-isotopic immunoassays have been widely investigated in recent years $(2-6)$. This paper describes the development and validation of a luminescence immunoassay (LIA) for human follitropin (follicle stimulating hormone, FSH), based on the synthesis of an FSH-N-(4-aminobutyl)-N-ethylisoluminol conjugate and a solid phase (magnetic particle) double antibody separation technique.

\section{Materials}

N,N-Dimethylformanide water-free $99+\%\left(\mathrm{H}_{2} \mathrm{O}<0.005 \%\right)$, Aldrich Steinheim 22-705-6.

N,N'-Dicyclohexyl-carbodiimide, Sigma, München, D 3128.

N-Hydroxysuccinimide Sigma, München, H 7377.

$\mathrm{N}$-(4-Aminobutyl)-N-ethylisoluminol (ABEI), 97\% pure, Sigma, München, A 0156.

Succinic anhydride, Sigma, München, S 7626.

Catalase from bovine liver, Sigma, München, C 3155.

Urea hydrogen peroxide $\left(\mathrm{H}_{2} \mathrm{O}_{2}\right.$ content approx. 35\%), Sigma, München, U 1753.

Sephadex G-50 fine, Pharmacia, Uppsala, particle size $20-80 \mu \mathrm{m}$.

1) Part of Ph. D. thesis of A. Samira.
FSH-human-pituitary Research Standard A, 4 IU/Ampoule (MRC London).

Follitropin highly purified batch CPD 313 (3500 IU/mg) (generous gift of Prof. W. R. Butt, Dept. of Clin. Endocrinology, Birmingham, Midland Hospital for Women, England).

Rabbit-anti-FSH-antibody Hoe-RCL-2665, Hoechst AG, Frankfurt/Main.

FSH-IRMA kit Nichols Institute, San Juan Capistrano, Calif., USA.

MAIA Reagent (Anti-rabbit IgG covalently bound to paramagnetic particles), Serono, Freiburg.

Berthold luminometer (CliniLumat LB 9502).

\section{Methods}

Tracer was prepared by a modification of the method of Barnard et al. $(2,3)$.

The reactions were carried out as follows:

Reaction a: $10 \mu \mathrm{mol} \quad \mathrm{N}$-(4-aminobutyl)-N-ethylisoluminol (ABEI; $2.76 \mathrm{mg}$ ) were dissolved in $160 \mu \mathrm{g}$ dry dimethylformamide in a water bath at $40-50^{\circ} \mathrm{C}$ for a few minutes, and 10 $\mu \mathrm{mol}(1 \mathrm{mg})$ succinic anhydride were dissolved in $2 \mathrm{ml}$ dry pyridine. Both solutions were gassed with dry nitrogen and mixed. The reaction tube was firmly plugged and left in the dark at room temperature for 24-72 hours.

Reaction b: Freshly prepared ABEI-hemisuccinamide (ABEI$\mathrm{H}$ ) was first made free of pyridine and dimethylformamide by distillation under low pressure in a vacuum distillation apparatus in the dark. The residue was dissolved in $25 \mu \mathrm{l}$ dry dimethylformamide and incubated with $10 \mu \mathrm{mol}(11.5 \mathrm{mg}) \mathrm{N}$ - 
hydroxysuccinimide and $30 \mu \mathrm{mol} \mathrm{N}, \mathrm{N}^{\prime}$-dicyclohexylcarbodiimide $(6.18 \mathrm{mg})$ in $40 \mu \mathrm{l}$ dry dimethylformanide (lotal incubation volume approximatcly $65 \mu$ l) for 24 hours in the dark.

Reaction c: $100 \mu \mathrm{g}$ highly purified follitropin was dissolved in $1000 \mu \mathrm{l}$ phosphate buffer $\left(\mathrm{Na}_{2} \mathrm{HPO}_{4} 0.05 \mathrm{~mol} / \mathrm{l}, \mathrm{pH} 8.0\right)$, and $200 \mu$ of this solution were incubated with $10 \mu$ of the reaction product " $b$ " (ABEI-hemisuccinamide active ester) at $4{ }^{\circ} \mathrm{C}$ for 24 hours in the dark.

The follitropin isoluminol conjugate was separated from the resulting mixture of reaction "c" by filtration on a column of Sephadex G-50 fine (length $25 \mathrm{~cm}$, diameter $1 \mathrm{~cm}$ ) using for elution $0.05 \mathrm{~mol} / \mathrm{l}$ Tris- $\mathrm{HCl}$ buffer $(\mathrm{pH} \mathrm{7.5)}$ containing 0.02 mol/l sodium azide. The eluate was collected in thirty $1 \mathrm{ml}$ fractions. Luminescence reactivity was measured in each fraction after dilution with Socrensen's phosphate buffer containing $10 \mathrm{~g} / \mathrm{l}$ bovine serum albumin using a Berthold luminometer.

The luminescence immunoassay was performed according to the scheme in table 1 . For use in the assay, the MAIA reagent was washed once in assay buffer, decanted and resuspended in the twofold buffer volume. After the second incubation, the tubes were decanted using a magnetic rack, washed three times with Soerensen's phosphate buffer $(10 \mathrm{~g} / \mathrm{l}$ bovine serum albumin) and catalase solution was added. Thereafter luminescence was measured in a Berthold luminometer, which automatically started the luminescence reaction by injecting urea hydrogen peroxide solution in the dark.

Tab. 1. Assay protocol for follitropin-LIA.

NSB: Non-specific tracer binding;

$B_{0}$ : Tracer binding in absence of unlabelled follitropin. MAIA: Anti-rabbit IgG covalently bound to suitable paramagnetic particles (suspension in assay buffer)

Assay protocol

\begin{tabular}{llll} 
Reagents & NSB & $B_{0}$ & $\begin{array}{l}\text { Standards } \\
\text { (samples) }\end{array}$ \\
\hline ABEI-H-follitropin & $100 \mu \mathrm{l}$ & $100 \mu \mathrm{l}$ & $100 \mu \mathrm{l}$ \\
$\begin{array}{l}\text { Assay buffer } \\
\text { Standards (samples) }\end{array}$ & - & - & $100 \mu \mathrm{l}$ \\
Follitropin antibody & - & $100 \mu \mathrm{l}$ & $100 \mu \mathrm{l}$
\end{tabular}

incubation for 20 hours at room temperature

$\begin{array}{ll}\text { MAIA suspension } & 25 \mu \mathrm{l} 25 \mu \mathrm{l} 25 \mu \mathrm{l} \\ & \text { incubation for } 10 \text { minutes at } \\ \text { room temperature } & \text { decant in magnetic rack and wash } \\ & 3 \text { times in Soerensen's phosphate } \\ \text { buffer (1 ml) containing } 10 \mathrm{~g} / \mathrm{l} \text { bo- } \\ \text { vine serum albumin }\end{array}$

Measure luminescence activity.

\section{Results}

Figure 1 shows that two peaks of luminescence were found in the eluates of the Sephadex G 50 fine column. When follitropin was measured in each eluate fraction by an immunoradiometric assay (Nichols Institute), peak 2 was found to be devoid of follitropin reactivity. The highest follitropin immunoreactivity was found in tubes 7-9 which were mixed for use as the luminescence tracer. The follitropin concentration of the combined fraction was approximately 1500

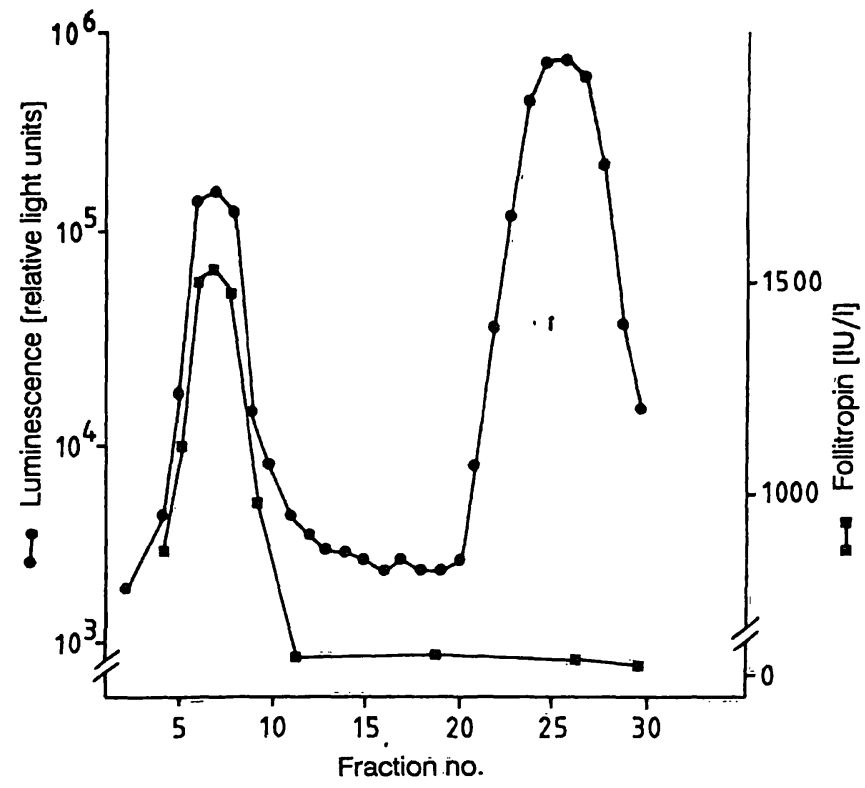

Fig. 1. Gel chromatographic pattern of the follitropin-ABEI$\mathrm{H}$-conjugate. The bulk of follitropin immunoreactivity is found in the first peak of luminescence.

RLU $=$ Relative light units.

IU/1. For use in the assay the mixture was diluted 75fold in assay buffer (Soerensen's phosphate buffer containing $30 \mathrm{~g} / \mathrm{l}$ bovine serum albumin) to yield a follitropin concentration of about $20 \mathrm{IU} / \mathrm{l}$.

Figure 2 shows a typical standard curve. The detection limit, defined as the follitropin concentration corre:sponding to the mean value of relative light units (RLU) minus two standard deviations of a twentyfold determination of the zero standard, was $0.59 \mathrm{IU} / 1$.

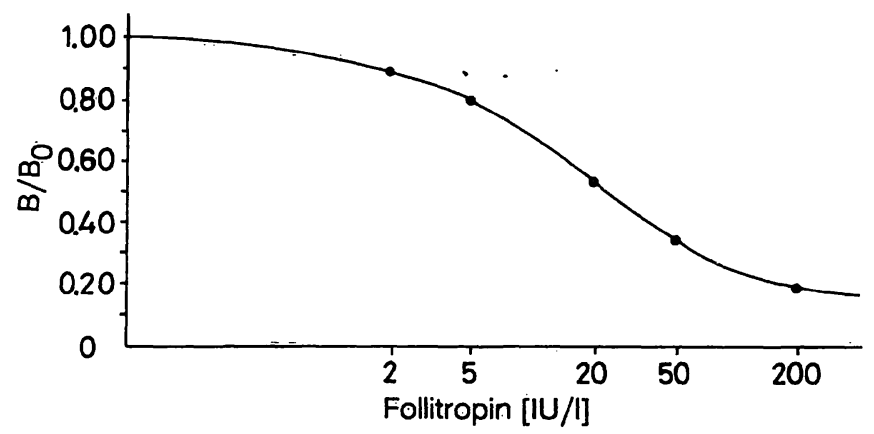

Fig. 2. Typical standard curve of follitropin-LIA. Detection limit $0.59 \mathrm{mIU} / 1$

\section{Precision profile}

Intraassay coefficients of variation were $4.8 \%, 3.1 \%$ and $6.7 \%$ in the ranges of 10,30 and $90 \mathrm{IU} / 1(\mathrm{n}=20)$ respectively. Interassay coefficients of variation were found to be $5.9 \%, 5.8 \%$ and $9.4 \%$ in the same ranges $(n=20)$.

The specificity of the antiserum used is demonstrated by the cross reactions at $50 \%$ inhibition (1): follitropin $100 \%$, thyrotropin $1.9 \%$, lutropin $0.2 \%$, human chorionic gonadotropin: unmeasurably low. 


\section{Accuracy}

Increasing amounts of standard were added to the same serum sample and aliquots were assayed (recovery test). Figure 3 demonstrates the straight regression line obtained for the added amount versus measured amount, demonstrating the equivalence of follitropin in standard and serum and the absence of matrix influences (see also tab. 2). Figure 4 shows the results of the parallelism test. Increasing dilutions of a serum sample with high follitropin concentration (menopausal serum) were assayed. The straight linear regression for the dilution factor versus the measured amounts of follitropin proved that the assay is independent of concentrations and interferences which may be present in the sample (see also tab.3).

Figure 5 demonstrates the excellent correlation of LIA results with IRMA values in 20 samples including 6 sera of menopausal patients, of one patient with primary hypogonadism, of 10 normal persons and of 3 patients with hypogonadotropic hypogonadism.

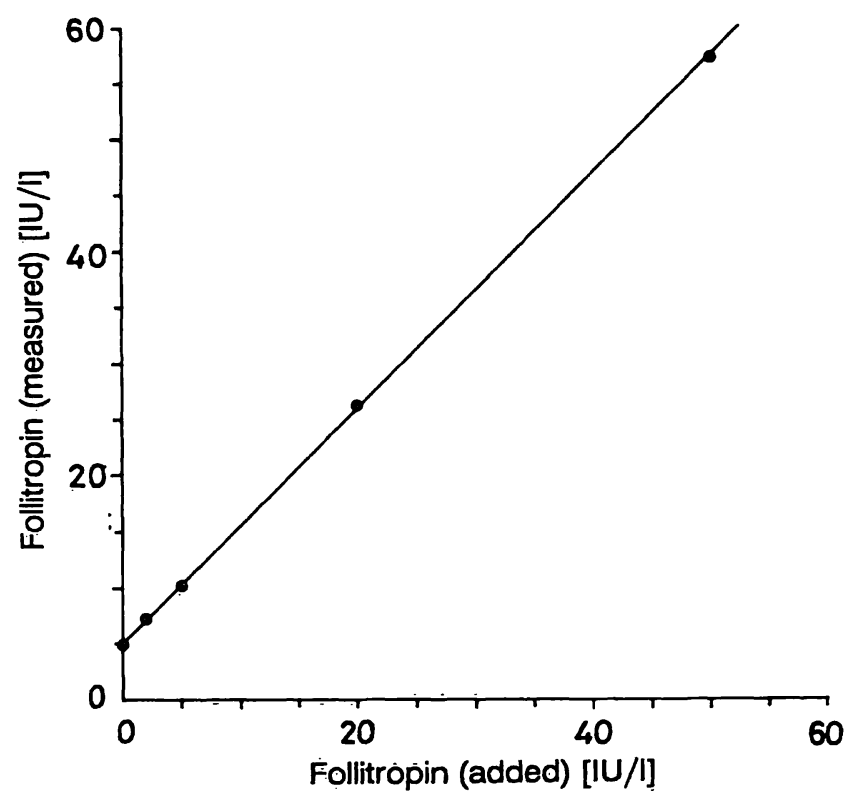

Fig. 3. Recovery test (see text) $\mathrm{y}=1.0504 \mathrm{x}+4.95 ; \mathrm{r}=0.9999 ; \mathrm{n}=4$.

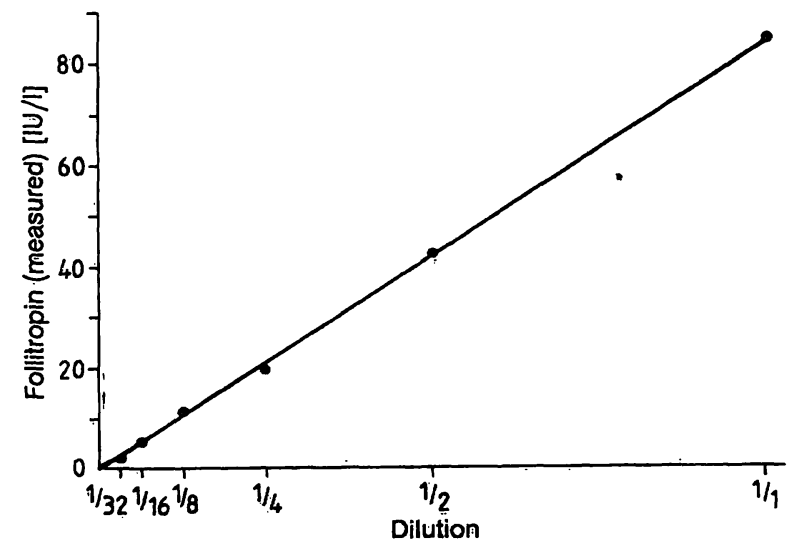

Fig. 4. Parallelism test (see text) $y=1: 01 x+1.9365 ; r=0.9991 ; n=6$
Tab. 2. Recovery test.

\begin{tabular}{llll}
\hline $\begin{array}{l}\text { Endogenous } \\
\text { follitropin } \\
\text { IU/1 }\end{array}$ & $\begin{array}{l}\text { Added } \\
\text { follitropin } \\
\text { IU/1 }\end{array}$ & $\begin{array}{l}\text { Expected } \\
\text { follitropin } \\
\text { IU/1 }\end{array}$ & $\begin{array}{l}\text { Recovered } \\
\text { follitropin } \\
\text { IU/I }\end{array}$ \\
\hline 4.8 & 0.0 & 4.8 & 4.8 \\
4.8 & 2.0 & 6.8 & 7.1 \\
4.8 & 5.0 & 9.8 & 10.0 \\
4.8 & 20.0 & 24.8 & 26.2 \\
4.8 & 50.0 & 54.8 & 57.4 \\
\hline
\end{tabular}

Tab. 3. Parallelism test.

\begin{tabular}{lll}
\hline Dilution & $\begin{array}{l}\text { Measured } \\
\text { follitropin } \\
\text { (IU/1) }\end{array}$ & $\begin{array}{l}\text { Result corrected } \\
\text { with dilution factor }\end{array}$ \\
\hline None & 86.6 & - \\
$1: 2$ & 42.5 & 85.0 \\
$1: 4$ & 19.8 & 79.2 \\
$1: 8$ & 11.2 & 89.6 \\
$1: 16$ & 5.4 & 86.4 \\
$1: 32$ & 2.4 & 79.2 \\
\hline
\end{tabular}

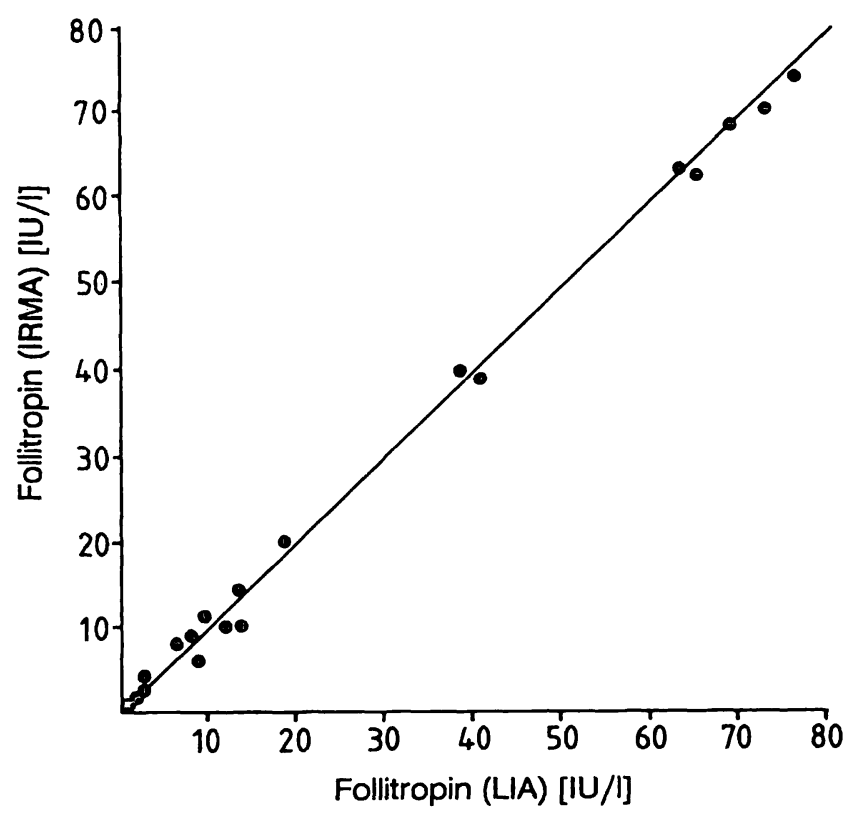

Fig. 5. Correlation of follitropin-LIA results with a reference follitropin-IRMA (Nichols Institute). $y=0,9907 x-0.1893 ; r=0.9987 ; n=20$.

\section{Discussion}

The use of radioactive tracers in immunoassays has certain drawbacks such as human contact with radioactive material and the short shelf life of the labelled antigens. The luminescence immunoassay (LIA) has solved these problems (4).

Follitropin determinations are being increasingly requested for the evaluation of patients with delayed puberty, amenorrhoea, pituitary tumours and infertility. We therefore developed - to the best of our knowledge for the first time - a follitropin LIA for 
clinical use. Labelling of highly purified follitropin with $\mathrm{ABEI}$ was performed in 3 subsequent steps in a modification of the method of Barnard et al. $(2,3)$. No attempt was made to purify the intermediate reaction products, because of the unstable nature of ABEI-hemisuccinamide active ester (7), and because final tracer purification was necessary anyway. The resulting stable follitropin-ABEI-hemisuccinamide conjugate was easily purified by gel chromatography. Many experiments were performed to find the optimal ratios for the final reaction of $\mathrm{ABEI}$-hemisuccinamide active ester with follitropin. Although the concentrations indicated above may not be optimal, they led to the highest quantity of the final reaction product. The conjugate has an excellent yield of luminescence

\section{References}

1. Abraham, G. E., Manlimos, F. S. \& Garza, R. (1977) Radioimmunoassay. In: "Handbook of radioimmunoassay" (Jaffe, B. M. \& Behrman, H. R., eds.) Academic Press, New York, p. 590.

2. Barnard, G. J., Kim, J. B., Brockelbank, J. L., Collins, W. P., Gaier, B. \& Kohen, F. (1984) Measurement of choriongonadotropin by chemiluminescence immunoassay and immunochemiluminometric assay. I: Use of isoluminol derivatives. Clin. Chem. 30, 538-541.

3. Barnard, G. J. \& Collins, W. P. (1987) The development of luminescence immunoassays. Med. Lab. Sciences 44, 249266.

4. Gadow, A., Fricke, H., Strasburger, C. J. \& Wood, W. G. (1984) Synthesis and evaluation of luminescent tracers and hapten-protein conjugates for use in luminescence immunoassays with immobilized antibodies and antigens. J. Clin. Chem. Clin. Biochem. 22, 337-347. impulses, very little non-specific binding and is stable for at least 9 months.

Separation of antibody-bound and non-bound tracer fractions was readily performed with a commercially available paramagnetic particle "second antibody" reagent. It proved to be essential to dilute this reagent in buffer containing only $10 \mathrm{~g} / 1$; albumin, as higher concentrations of albumin led to a quenching of luminescence activity. The assay can be performed at room temperature within 24 hours. It is well reproducible, has a sensitivity which allows the measurement of all clinically relevant values including subnormal ones, shows good correlation with a widely used commercial IRMA from a reference laboratory, and may therefore be recommended for clinical use.

5. Miska, W. \& Geiger, R. (1987) Synthesis and characterization of luciferin derivatives for use in bioluminescence enhanced enzyme assays. J. Clin. Chem. Clin. Biochem. 25, $23-30$.

6. Pazzagli, M., Kim, J. B., Messeri, G., Kohen, F., Bolelli, G. F., Tommasi, A., Salerno, R., Moneti, G. \& Serio, M. (1981) Luminescent immunoassay (LIA) of cortisol - I. Synthesis and evaluation of two chemiluminescent labels of cortisol. J. Steroid Biochemistry 14, 1005-1012.

7. Butz, H. (1989) Entwicklung und Optimierung eines Lumineszenzimmunoassay zur quantitativen Bestimmung von LSD in Urinproben. Doctor-thesis, Saarland-University, Saarbrücken, pp. 115-124.

Priv. Doz. Dr. G. Biro

Medizinische Klinik und Poliklinik

W-6650 Homburg/Saar

Bundesrepublik Deutschland 